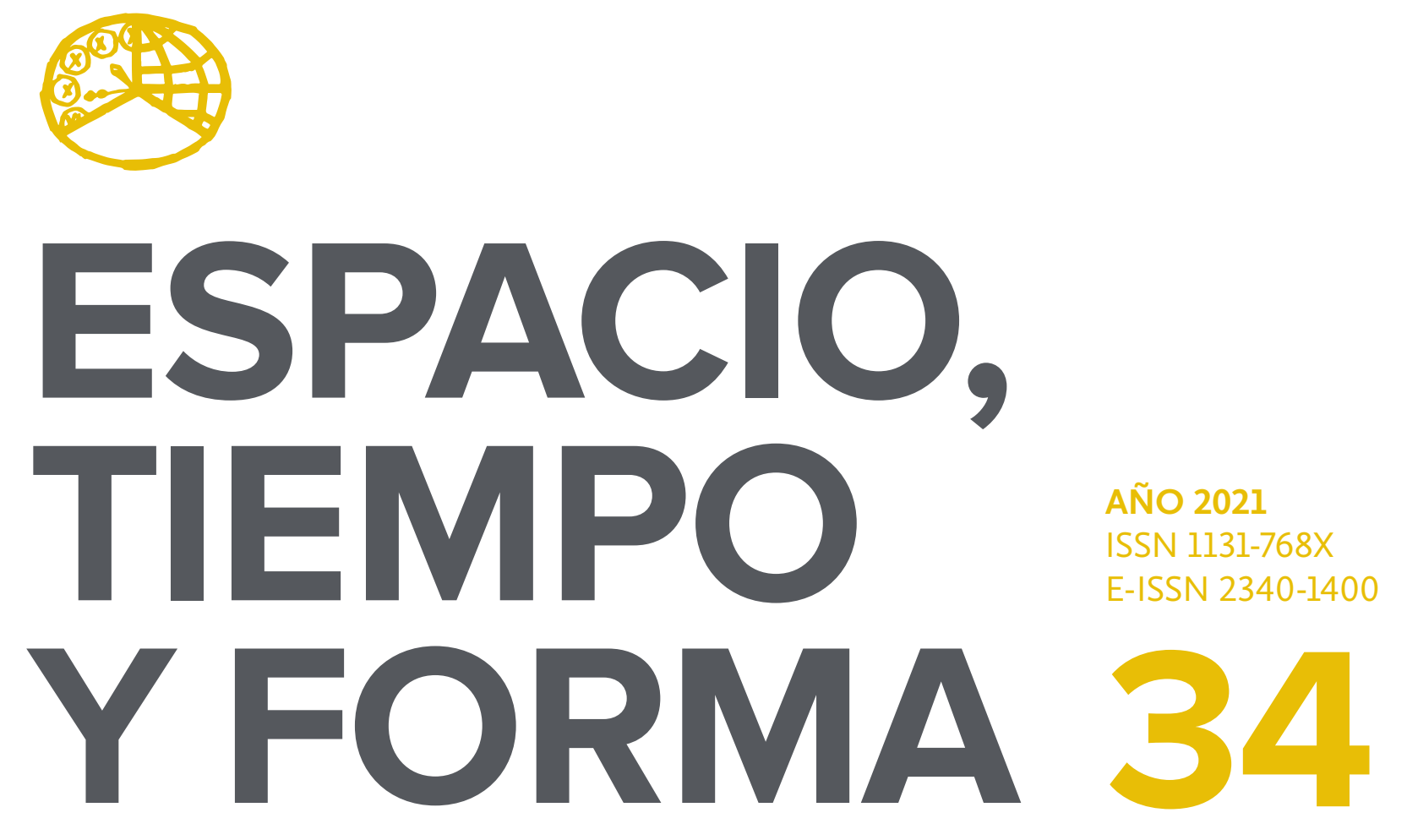

SERIE IV HISTORIA MODERNA

REVISTA DE LA FACULTAD DE GEOGRAFÍA E HISTORIA

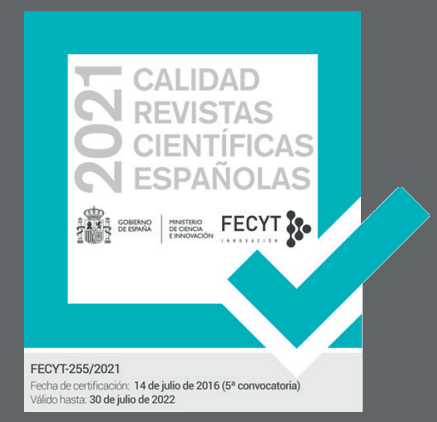




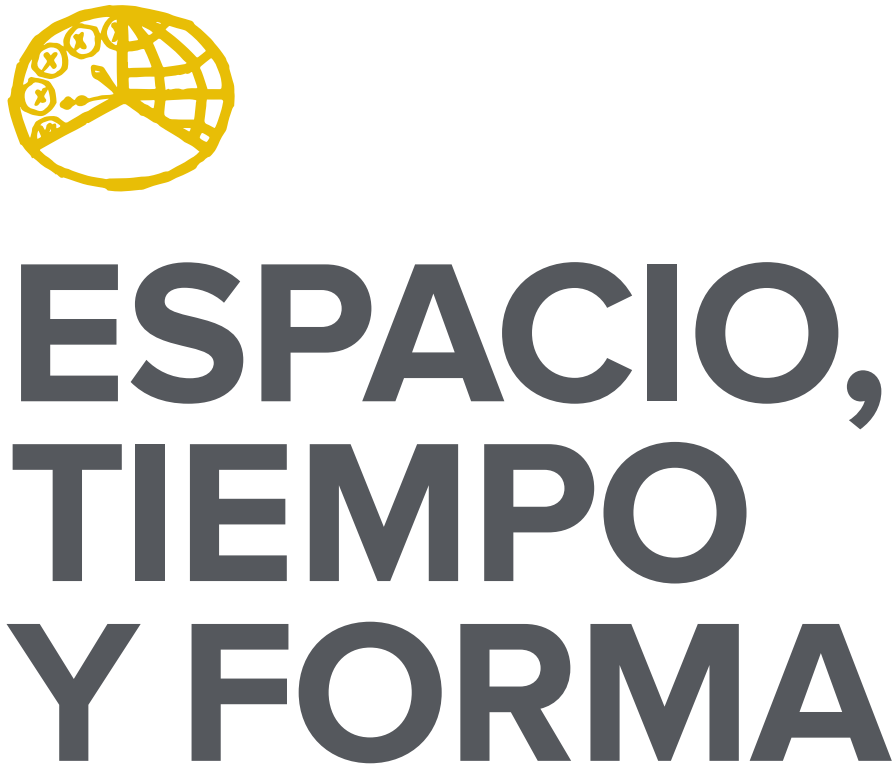

AÑO 2021

ISSN 1131-768X

E-ISSN 2340-1400

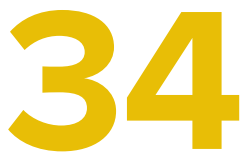

SERIE IV HISTORIA MODERNA

REVISTA DE LA FACULTAD DE GEOGRAFÍA E HISTORIA

DOI: https://doi.org/10.5944/etfiv.34.2021

\section{UกED}

UNIVERSIDAD NACIONAL DE EDUCACIÓN A DISTANCIA 
La revista Espacio, Tiempo y Forma (siglas recomendadas: ETF), de la Facultad de Geografía e Historia de la UNED, que inició su publicación el año 1988, está organizada de la siguiente forma:

$$
\begin{aligned}
& \text { SERIE I - Prehistoria y Arqueología } \\
& \text { SERIE II - Historia Antigua } \\
& \text { SERIE III - Historia Medieval } \\
& \text { SERIE IV - Historia Moderna } \\
& \text { SERIE V - Historia Contemporánea } \\
& \text { SERIE VI - Geografía } \\
& \text { SERIE VII - Historia del Arte }
\end{aligned}
$$

Excepcionalmente, algunos volúmenes del año 1988 atienden a la siguiente numeración:

$$
\begin{aligned}
& \mathrm{N} .^{\circ} 1 \text { - Historia Contemporánea } \\
& \mathrm{N}^{\circ} 2 \text { - Historia del Arte } \\
& \mathrm{N} .^{\circ} 3 \text { - Geografía } \\
& \mathrm{N} .^{\circ} 4 \text { - Historia Moderna }
\end{aligned}
$$

ETF no se solidariza necesariamente con las opiniones expresadas por los autores.

\author{
UNIVERSIDAD NACIONAL DE EDUCACIÓN A DISTANCIA \\ Madrid, 2021 \\ SERIE IV · HISTORIA MODERNA N. ${ }^{\circ} 34,2021$ \\ ISSN $1131-768 X \cdot$ E-ISSN 2340-1400 \\ DEPÓSITO LEGAL \\ M-21.037-1988 \\ URL \\ ETF IV · HISTORIA MODERNA · http://revistas.uned.es/index.php/ETFIV \\ DISEÑO Y COMPOSICIÓN \\ Carmen Chincoa Gallardo · http://www.laurisilva.net/cch \\ Impreso en España · Printed in Spain
}

(c) (7) (8) Esta obra está bajo una licencia Creative Commons Reconocimiento-NoComercial 4.0 Internacional. 


\section{MISCELÁNEA • MISCELLANY}





\title{
FÁBULAS DE ORIGEN Y GRAMÁTICA DE NACIÓN EN LA ESPAÑA DEL SIGLO XVIII. A PROPÓSITO DE ALGUNOS TRABAJOS DE FRANCISCO MARTÍNEZ MARINA
}

\author{
ORIGIN'S FABLES AND GRAMMAR OF NATION \\ IN THE XVIII CENTURY SPAIN. ABOUT SOME \\ WORKS BY FRANCISCO MARTÍNEZ MARINA
}

\author{
Pablo Fernández Albaladejo \\ Recibido: 02/07/2021 - Aceptado: 06/09/2021 \\ DOI: https://doi.org/10.5944/etfiv.34.2021.31827
}

\begin{abstract}
Resumen
Habitualmente recluida dentro del ámbito estricto de la historia jurídica y constitucional, la obra de Martínez Marina encierra no obstante una pluralidad de registros que últimamente empieza a ser reconocida. Estas páginas intentan llamar la atención sobre la nueva perspectiva en la que Marina -con una larga mirada histórica y una actualizada historiografía comparativa- planteó la gestación y el papel que necesariamente tenía que jugar la lengua en la construcción de la identidad española. En un planteamiento innovador Marina puso de manifiesto la imposibilidad de constituir la nación si, previamente, no se dotaba de constitución a la lengua propia.
\end{abstract}

Palabras clave

Francisco Martínez Marina; Lengua; Nación; Identidad; Orígenes

\section{Abstract}

Usually confined within the strict scope of legal and constitutional history, Martínez Marina's writings nevertheless contain a plurality of records that lately have begun to be recognized. These pages try to draw attention to the new perspective in which Marina - with a long historical gaze and updated comparative historiography raised the gestation and the role that language necessarily had to play in the construction of the Spanish identity. In an innovative approach, Marina revealed

\footnotetext{
1. Universidad Autónoma de Madrid; pablo.albala@uam.es

Este trabajo forma parte del proyecto de investigación PGC2018-095007-B-loo financiado por el Ministerio de Ciencia e Innovación.
} 
the impossibility of constituting the nation if, previously, the own language was not provided with a constitution.

Keywords

Francisco Martínez Marina; Language; Nation; Identity; Origin 
COINCIDIENDO con la transición del siglo XVIII al XIX Martínez Marina daba a luz dos trabajos puntualmente recogidos dentro de las publicaciones de la Real Academia de la Historia. Se trata en concreto de las Antigüedades hispano-hebreas convencidas de supuestas y fabulosas. Discurso histórico-crítico sobre la primera venida de los judíos a España aparecido en 1799 y, con fecha ya de I805, del Ensayo históricocrítico sobre el origen y progreso de las lenguas, señaladamente del romance castellano. No parece que en su momento -y a diferencia de lo sucedido con otras obras del autor- suscitasen un gran interés. En cierto sentido acabaron varados en tierra de nadie. Atentos sobre todo a la vertiente político-constitucional del autor, las Antigüedades y el Ensayo no constituyen referencia frecuente entre los estudiosos de su pensamiento. Una ausencia que no se produce en el caso de los historiadores de la lengua quienes, con la vista puesta en el Ensayo, no consideran por lo demás que este último suponga una aportación relevante en la trayectoria de su disciplina ${ }^{2}$. Atrapada en ese fuego cruzado de especialidades, la obra de Marina resulta privada de una información que, como tendremos ocasión de ver, enriquece con nuevas perspectivas la compleja trayectoria del autor ${ }^{3}$.

Desde el observatorio de una llustración nacional en su tramo final, Marina avanzó los supuestos de un nuevo relato identitario español que su Teoría de las Cortes de I8I3 se encargaría de formalizar. Antes de esbozar un país constitucional, nuestro clérigo cuidó de dejar en claro una serie de cambios que previamente habían hecho posible ese desenlace y que, en última instancia, implicaban la revisión de algunos de sus mitos fundacionales. Cambios que partiendo de una nueva lectura sobre el oscuro momento de los orígenes de la nación, concluían poniendo de manifiesto la importancia del hecho lingüístico. La indagación sobre la lengua propia jugó en este sentido un papel crucial, ofreciéndose como suelo insustituible y cemento integrador a la hora de consolidar ese relato de nación.

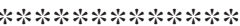

El primero de los trabajos al que nos hemos referido, las Antigüedades hispanohebreas, se hacía eco de las nuevas perspectivas abiertas en relación con los tiempos remotos. Indagaba sobre unas genéricas antigüedades cuya entidad venía siendo objeto de un intenso debate a raíz de la crisis de la conciencia europea y en el que la relectura de la Biblia pasó a ocupar un lugar central ${ }^{4}$. El progreso de la crítica bíblica dio paso a lo que F. Laplanche ha llamado una «reescritura del mito cristiano», tarea que durante mucho tiempo ocupó a los miembros más conspicuos de la republica de las letras y que, inevitablemente, puso de manifiesto contradicciones fundamentales entre el saber bíblico y las propuestas de la nueva ciencia (sobre la lengua primera, sobre los orígenes de las naciones, sobre la cronología y geografía sagradas). Marina se situaba en la estela de ese debate, al que la tradición de la Real

\footnotetext{
2. Martínez Marina, 1799 y 1805 . Sobre el Ensayo puede verse, Ridruejo, 2006: 825-837

Sobre esa trayectoria ver, Fernández Albaladejo, 2007: 323-350. WeStLer, 2015.

4. LAPLANCHE, 1994: 33-48. DroIXHE, 1992: 65-99. RossI, 1979: cap. II.
} 
Academia de la Historia y su condición de académico y director de la misma desde I796 le obligaban. Su mirada nacionista no era ajena a su forma de plantear el tema: más que hispano-hebreas, sostenía Marina, las antigüedades debían de contemplarse como sólo nuestras, como sólo hispanas. En realidad, la presencia de los judíos en el pasado español más remoto no dejaba de ser sino una «fábula pueril», por lo que no cabía admitirlos como compañeros de viaje desde los tiempos primeros. Los judíos ciertamente podían ser «célebres por su religión», pero resultaban «despreciables por su rusticidad e ignorancia en el comercio, artes y ciencias». Y era esa condición de contramodelo de la modernidad -y no su religión- lo que les convertía en un insufrible «lunar» de la «historia nacional»5.

Impulsado por el mismo incontenible «amor nacional» que había movido a otros «claros varones» antes que él (Nicolás Antonio, el marqués de Mondéjar), Marina advertía que la historia de «nuestras antigüedades» tenía mucho que rectificar. Considerando que actuaba en nombre de la «integridad» que debía presidir «nuestra historia nacional», Marina se proponía mostrar las «fábulas» que literatos propios y extranjeros habían sembrado en relación con esas antigüedades en las que -además de fenicios, troyanos, griegos, asirios, caldeo, persas, cartagineses y romanos- habían terminado «introduciendo en ellas a los hebreos». Eran algunos de esos modernos (los hermanos Mohedano, Francisco Masdeu) ${ }^{6}$ sobre quienes recaía buena parte de esa responsabilidad que, en última instancia, había llevado a que las «tinieblas» se hubiesen hecho más densas «en tiempos de las mayores luces». Marina censuraba la credibilidad que esos autores habían venido otorgando a unos textos y a una historia que, como la del Tarsis español, sólo podía ser considerada como «supuesta y fabulosa»; sobre todo cuando ya desde del siglo XVII autores como el Marqués de Mondéjar (Cádiz Phenicia) habían manifestado serias dudas a ese respecto ${ }^{7}$. Rechazaba por ello la existencia de los «viajes y comercio con España» que supuestamente habrían venido practicando los judíos «desde el tiempo de Salomón». Más en concreto, la identificación y localización que ambos defendían a propósito de la localización en España de Tarsis y Ofir, los lugares a los que se dirigían las flotas de Salomón, encubría, en realidad, una mala interpretación de lo que refería el propio texto sagrado ${ }^{8}$. Haciéndose eco de las cuestiones planteadas en su momento por autoridades como Samuel Brochart y Daniel Huet ${ }^{9}$, Marina, cien años después, se consideraba obligado a denunciar la sorprendente continuidad de un estado de cosas que -dentro del ámbito cultural español- debería darse ya por concluido.

5. Martínez Marina, 1799a: 318-19.

6. Rodríguez Mohedano, 1766-1791. Masdeu, 1783-1805.

7. IBÁÑEZ dE SEgOVIA, 1805, con una completa relación de los autores que anteriormente se habían pronunciado en el mismo sentido, confeccionada probablemente a fines del XVII. Sobre autor y contexto Fernández Albaladejo, 2015

8. Sobre esa tradición, LIDA DE MALKIEL, 1970. El descubrimiento de América aumentó la complejidad de esa identificación, especialmente en el caso de Ofir. Véase GIL, 1980: 226-250. G. GLIOzZI, 1977: 177-247; y una perspectiva de conjunto en POULOIN, 1998: 234-265.

9. Brochart, 1646. Huet, 1693, 1701 y 1716. Sobre ellos, Pouloin, 1998: 253-267. Laplanche, 1994: 39. 
Bien es verdad que tampoco faltaban interpretaciones de orden más tradicional y circunscritas al tema, aunque Marina parecía -o aparentaba- ignorarlas. Entre ellas se contaba la España en la Santa Biblia. Exposición historial de los textos tocantes a Españoles de Fr. Pablo Yañez de Avilés, un cisterciense que en la fecha de aparición del libro (1733) ocupaba el cargo de Chronista de Su Magestad y de sus Reynos de España. Con un título que ya en sí mismo resultaba suficientemente expresivo, Yañez acreditaba la validez de los nombres de España que aparecían en el texto sagrado. De acuerdo con su dictamen no había razón para negar la presencia de judíos en España «antes de la promulgación del Evangelio» y, menos aún, para considerar que su venida hubiese sido «ignominiosa a España» $»^{10}$. Sin referirse expresamente a la obra del cisterciense y ateniéndose a las reglas de «la más sana crítica», Marina dejaba constancia en cualquier caso del silencio de la Historia Sagrada a la hora de precisar «la situación geográfica» de los lugares en cuestión. La ubicación en España del Tarsis de la Historia Sagrada» debía de incluirse sin más «en el orden y catálogo de las fábulas». La misma consideración le merecía por ello la presencia de aquellas pruebas patrias que, como las inscripciones hebreas encontradas en Murviedro (Sagunto), se presentaban como demostración inequívoca de «la veracidad del imperio de Salomón en España». Bastaba la sola aplicación de las «reglas de crítica y buen juicio» para advertir que tales inscripciones eran «apócrifas», consecuencia todo ello de un tiempo en el que «se ignoraba la «buena filosofía y las reglas de la crítica». Al decir de Marina fue justamente el restablecimiento del «buen gusto y la literatura en España» lo que había permitido al marqués de Mondéjar rechazar la «impostura» sobre «la antigua venida de los judíos a España». Y esa era la senda en la que él mismo intentaba situarse, convencido de que se trataba de una misión ineludible contra quienes, con sus «ardides», atentaban contra «la integridad y pureza de nuestra historia nacional» ${ }^{\text {II }}$.

Ya se ha visto que independientemente de situar en su debido lugar la presencia de los judíos en el pasado hispano, Marina remitía asimismo a cuestiones de metodología histórica. Denunciaba la continuidad y la credibilidad que colegas cercanos -en contra de las reglas de crítica - venían otorgando a la fábula como sostén argumental del relato de las antigüedades propias. Con toda probabilidad el hecho de que en I796 se hubiese vuelto a publicar en las Memorias de la Academia una Disertación sobre si la Mitología es parte de la Historia, y como deba entrar en ella ${ }^{12}$ no era ajena a esa inquietud. Su autor, Francisco Manuel de la Huerta (I697-I752), académico de las Reales de la Lengua y de la Historia, había publicado entre 1738 y I740 una España Primitiva. Historia de sus reyes y monarcas desde su población hasta Christo, objeto en su momento de una censura demoledora por informadores tan señalados como Gregorio Mayans y Martín de Sarmiento. Crítica aparte, la Disertación de

10. YAÑEZ de AVILÉS: 1733, parte I, caps IX y X y para las referencias a Tarsis y Ofir, 105, 180 y 185 .

11. Martínez Marina, 1799: 320, 395, 405-418, con un detallado análisis sobre las incongruencias lingüísticas y estilísticas. Ver también obre ese momento, MORA, 2010: 446-47. Marina se refería en concreto a autores como Benito Arias Montano y Esteban de Garibay, si bien el mayor peso recaía sobre Juan Román de la Higuera (ver últimamente García-Arenal y Rodríguez, 2010: 222-228. OLdS, 2015: cap. IV).

12. De LA HUERTA, 1740. 
Huerta estaba lejos de resumirse en una audaz incursión por tierras desconocidas. Constituía en realidad una de las cuestiones centrales que desde i 680 venían planteándose en el seno de la Querelle des Anciens et des Modernes en relación con la posibilidad de que las figuras y mitos de la fábula pudieran ser utilizados como testimonios con los que armar un relato acorde con las exigencias de certeza de la nueva episteme historiográfica ${ }^{\text {13 }}$. Denotando un cierto paralelismo con la actuación y el posicionamiento de l'Académie des Inscriptions et Belles-Lettres, la Academia española, con la publicación de la Disertación, parecía querer entrar en el debate concediendo tácitamente a Huerta el papel de introductor.

La España primitiva propuesta por Huerta podía ser tildada -como había hecho Mayans- de España imaginaria, pero la connotación de falsario que recaía sobre él por sus manejos historiográficos no deben hacernos perder de vista esa otra vertiente de su obra, especialmente por las nuevas expectativas que abría para adentrarse en la historia de los orígenes. Partiendo de un evemerismo militante, la historia de los Atlántidos españoles que poblaron la España primitiva ponía de manifiesto una incomparable genealogía nacional, en tanto que sus gestas les conferían la condición de pueblo instituyente. Huerta se situaba así dentro de lo que Pierre Vidal-Nacquet he llamado el «atlanto-nacionalismo», una corriente liderada por la Atlantica sive Manheim de Olaus Rudbeck (I679) y que, de manera resuelta, apostaba por unas raíces europeas alejadas de la herencia griega ${ }^{\mathrm{I}}$. La reivindicación de los pueblos del norte a los que se acogía Rudbeck coincidía con el ascendiente papel de los pueblos de oriente expuesto por Bochart en su Geographia, un orientalismo que reclamaba raices filoegipcias para la cultura europea y en el que se incluían eruditos hispanos de la talla de Tomás de León y el propio Mondéjar; su Cádiz Phenicia era una temprana y sólida demostración al respecto. Aunque habitualmente incluidos dentro del relato historiográfico, la presencia y el papel de los fenicios en el pasado peninsular adquirió una creciente visibilidad en la primera mitad del siglo XVIII' ${ }^{15}$.

El contexto político no era ajeno a esa irrupción. Propiciada por la inestabilidad interna que supuso la instauración de los Borbones y, no menos, por la necesidad de redifinir la entidad de la propia comunidad política, la historia antigua se sitúo en una posición estratégica en la construcción de un nuevo relato identitario. La España de Huerta como ya se ha visto se situaba en esa encrucijada, y a ella respondían asimismo los Anales de la Nación española desde el tiempo más remoto hasta la entrada de los romanos publicados en 759 y obra de Luis José Velázquez, marqués de Valdeflores. Vinculado con la facción ensenadista que había accedido al poder en 1747 y miembro de la Real Academia de Historia desde I752, Valdeflores jugó un papel fundamental dentro del plan de reconstrucción cultural impulsado por el sector ensenadista y puesto en marcha por la Real Academia. En su condición de miembro de la comisión científica para la recuperación del legado histórico de la nación, a Valdeflores se le asignó la parte relativa a la Historia Civil, tarea en la que durante

13. BORGHERO, 1983: caps. 1-3

14. LaURenS, 1989: 205-218. Sobre la Atlántida, VIDAL-NACQUet, 1987 y 2005. ErikSSON, 1994.

15. Cruz Andreotti y Wulff Alonso, 1993: 171-189 y 1993b: 75-94. 
dieciocho años desplegó una actividad incansable recogida en su Noticia del viage a España (1765). En ella se exponía el Plan de una nueva Historia general de España que incluía «no solo la misma Historia, sino también las pruebas de ella», esto es, «los antiguos Documentos en que se funda». Como él mismo hacía notar, era «la primera vez que se ha aplicado a la Historia de España el método analítico, y lo que en toda clase de Escritos es el espíritu más filosófico». El conflicto entre erudición y filosofía que recorre la llustración europea se hacía así notar. Eran diferencias de partida de las que importaba dejar constancia ${ }^{16}$.

Consecuente con esos supuestos, Valdeflores desplegaba un diseño metodológico que sistematizaba «todos los más menudos artículos de la antigua Historia de la Nación distribuidos según el orden natural de los ramos de esta misma Historia». Dentro de esos ramos, los documentos históricos se ordenaban en diplomáticos, inscripciones, medallas, pintura, escultura, arquitectura, muebles, utensilios de la vida civil... una enumeración que estaba lejos de sobreentenderse como un informal depósito de referencias. Cada uno de esos apartados iba precedido por el término «ciencia», es decir, «la noticia y teoría de ellos [los documentos] relativamente a su conocimiento y uso». Frente a la lectura del pasado remoto sustentado básicamente sobre la evidencia literaria, Valdeflores proponía una mirada que podría decirse arqueológica. Su plan se inscribía dentro de una dinámica europea iniciada a mediados del siglo anterior y magistralmente resumida en su momento por Arnaldo Momigliano. Su objetivo era construir relatos de historia en los que la evidencia «se estableciese en base a monedas, inscripciones y restos arqueológicos $»^{17}$. La utilización de la evidencia no-literaria adquiría un reconocimiento pleno dentro del quehacer del historiador, con la inevitable consecuencia de que documentos, inscripciones y monedas empezasen a aparecer tan fiables -sino más- que la evidencia literaria basada en la tradición ${ }^{18}$.

El panorama que se contempla en trabajos como el Ensayo sobre los alfabetos de las letras desconocidas que se encuentran en las más antiguas Medallas y Monumentos de España (1752) o en las Conjeturas sobre las medallas de los Reyes suevos y Godos de España (1759) muestra la entidad del cambio en la manera de analizar la historia antigua. Miraflores dejaba constancia de las posibilidades de la nueva metodología que venía aplicándose en determinados sectores del ámbito cultural francés, de cuya Académie Royale des Inscriptions et Belles Lettres era correspondiente. Sus Anales de la Nación Española, con pretensión de remontarse hasta el tiempo más remoto, marcan claramente la diferencia en relación con la España de Huerta, informado como sabemos de esas orientaciones, pero cuya opción nada tenía que ver con la de Miraflores. Este último no rehuía la mitología como encuadramiento formal necesario, ni excluía tampoco la división de tiempos de Varron. Pero en el momento

16. Sobre la trayectoria de Valdeflores, Álvarez MARTí-Aguilar, 1996. Las referencias que se citan proceden de VeLÁzQUez, 1765: 29-30.

17. Momigliano, 1950: 293, 298 y 304.

18. Dentro siempre de unos límites. Como ha hecho notar Alain SCHNAPP (1991), el objeto no dejaba de ser sino una manera de «acceder a la historia por una vía más directa», más fiel si se quiere que la de los textos, pero sometido siempre a una interpretación que seguía siendo filológica antes que propiamente arqueológica. 
de establecer una cronología Miraflores dirigía su mirada a la novedosa y discutida propuesta de Newton expuesta en su The Cronology of Ancient Kingdoms Amended (I729), cuyo Sistema intentaba aplicar a la Historia Antigua de España ${ }^{19}$.

Partiendo del tiempo desconocido el relato de la historia antigua se configuraba en clave de «orígenes de la Nación». No sin advertir que esta última sufría del mismo «vano empeño que todas las demás» por remontar sus «primeros orígenes a un tiempo muy remoto», una demostración para Miraflores de la «debilidad humana» cuando actuaba «abandonada de la razón y de la Philosophia ${ }^{20}$. Tratándose de un tiempo «a que no alcanza la memoria y de cuyas cosas no se ha conservado monumento», las más que dudosas fuentes a las que alternativamente podía recurrirse imposibilitaban cualquier cómputo. En todo caso -y como reconocimiento obligado de un momento primero- cabía admitir que los españoles descendían de Tarsis, biznieto de Noe, una opción que tampoco estaba exenta de implicaciones: por una parte, desafiaba toda una tradición que venía depositando en Tubal, nieto de Noe, ese papel fundacional y, sobre todo, daba nombre a los primeros pobladores de España y localizaba a Tartessos como un «País» situado en «las costas de la Bética». Tartessos se constituía en la referencia fundamental de ese momento civilizador que, independientemente de acoger en su seno el origen de la monarquía propia hacía resaltar su no dependencia de la cultura griega y su mayor antigüedad. Acoplándose decididamente a la cronología y al orientalismo newtoniano, Valdeflores procedía a exponer una genealogía cultural de los españoles al margen de las influencias hebreas, vinculando sus raíces con la llegada de la prestigiosa civilización de los fenicios. Como él mismo hacía notar, el papel de los fenicios curetes era similar al que en su momento habían desempeñado druidas y bardos galos y, asimismo, con los salios latinos. La península se dotaba así de un referente que situaba a la nación española dentro del renovado mapa de los orígenes, tal y como para el caso de los celtas venían proponiendo autores como el padre Pezron ${ }^{21}$.

La filiación fenicia minimizaba el interés por la genealogía primera, por la conexión bíblica. La propia presencia de Tarsis resultaba en cierto sentido impostada, casi innecesaria. En esa línea no cabía tampoco la reivindicación de la Atlantida. En un rechazo implícito de la interpretación de Huerta, el texto platónico sólo cabía ser entendido como una «historia de los Reyes de Egypto». En la nueva perspectiva que se abría, el foco de interés debía dirigirse hacia los fenicios, tal y como ponían de manifiesto la serie de trabajos de los que tenemos constancia en la primera mitad del siglo ${ }^{22}$. Inevitablemente la construcción del relato fenicio abrió las puertas a una reflexión sobre la presencia cartaginesa, contemplada asimismo desde nuevos supuestos. No se trataba de una estricta cuestión de historia interna, ni la mirada era sólo cultural. El protagonismo de Cartago era europeo y formaba parte del enfrentamiento por la hegemonía continental entre el absolutismo francés y el constitucionalismo británico que, de la mano de estos últimos, presentaba a

19. Álvarez Martí-Aguilar, 1996: 104; sobre el contexto, Grell, 1995: 809 y ss.

20. Una perspectiva general en Rossı, 1979: 199-210.

21. VelázqueZ, 1765: 113, 119-120. Sobre el celtismo de dom Paul Pezron, GreLL, 1995: 1119-23.

22. Mederos MARTIN, 2012: 15-33. 
Cartago como un precoz modelo republicano y comercial concorde con la configuración de las islas británicas ${ }^{23}$. Salvando las distancias, la edición en 1756 de la Antigüedad Maritima de la Republica de Cartago con el periplo de su General Hannon llevada a cabo por Campomanes trataba de exponer algunas de las excelencias de ese modelo que, de otra parte, tampoco resultaba un cuerpo extraño dentro de la historia peninsular. Las memorias encerraban «muchas antigüedades» en relación con «el Comercio y Navegación de los primitivos españoles», antigüedades que en última instancia podían servir como «basa del Imperio del mar propio de la Corona de V. Mag.». Esos eran los primitivos por los que cabía interesarse, ellos estaban en el origen de «las memorables empresas y lejanos descubrimientos» llevados a cabo posteriormente por la «Nación Española» ${ }^{24}$.

Al margen de ese supuesto nacionista, la edición del periplo de Hanon confirmaba la consolidación del orientalismo en la España de la segunda mitad del siglo XVIII, propiciada desde las Academias de Historia y de la Lengua. Uno de los miembros más destacados de esta última, Pérez Bayer, llevaría a cabo una investigación sobre el hebreo basada en la convicción de que esa lengua poseía la clave para descifrar las escrituras impresas en las llamadas monedas «desconocidas» españolas, «es decir, ibéricas y celtibéricas» ${ }^{25}$. Poco antes $-y$ en esa misma línea- Cándido María Trigueros, en su Discurso persuadiendo el estudio de la lengua hebrea (I773), hacía notar que ya habían concluido «aquellos oscuros tiempos en que nuestros escritores nos vendían las fábulas de los Tubales o los Tarsis», enfatizando por contra el hecho de que «nuestra España» conocía ya «deber su primera población o, a los Celtas por tierra, o por mar a los Phenicios y Cartagineses»; a los idiomas de estos últimos se reducían en realidad «nuestras primitivas memorias» cuyo conocimiento sólo podía alcanzarse a través del hebreo ${ }^{26}$. Cabía finalmente una propuesta aún más radical que nadie formuló con más contundencia que el jesuita Esteban Terreros en el prólogo a su Diccionario de $1786^{27}$ : «Sea el Lenguaje primitivo de España el que se fuese: háyanos venido con Tubal o Tarsis», pero - precisaba a continuación- a la vista estaba que el paso de naciones extranjeras por la península había terminado por conformar una «lengua Franca» que hacía imposible determinar «cuál fuese el fondo de tan despedazado idioma». Lo que no impedía que, haciendo de la necesidad virtud, el jesuita diese la vuelta a lo que pudiera esperarse de ese estado de cosas. Sucedía que después de tan reñidas batallas «la ruina misma se nos ha convertido en riqueza», que «los encuentros y la mezcla de palabras» subsiguientes a «las entradas de tantas naciones» nos había dejado «tanto botín» que compensaba cualquier pérdida del lenguaje primitivo. Más aún: la fecundidad de ese enriquecido magma ponía de manifiesto la presencia de un «idioma» que contenía «como parte propia y esencial suya, el de las ciencias y artes mecánicas liberales», habilitándonos

23. DZIEMBOWSKY, 1998: 182-191, 238-247.

24. Rodríguez Campomanes, 1756. Almagro-Gorbea, 2003: 117-159.

25. Mora, 2010: 440-7. EIROA Rodríguez, 2012: 245-253.

26. Aguilar Piñal, 2001: 85.

27. Terreros y PANDO, 1786-1793: I, i-v. 
en consecuencia para emprender una obra que, como el Diccionario, «concebía utilísima a la nación».

*********************

El propio Pérez Bayer no ocultaba las expectativas que se abrían ante el nuevo rumbo que empezaban a tomar la perspectiva de los orígenes, especialmente en relación con aquellas cuestiones que deberían protagonizar la investigación inmediata. Como él mismo reconocía en I78I, su interés por los estudios monetarios no era sino una forma de acceder al conocimiento de «nuestra primitiva literatura y población». Una propuesta que, a esas alturas, no podía decirse que tuviese mucho de novedosa. De hecho formaba parte del debate en torno a los orígenes del lenguaje que se venía librando en el seno de la llustración europea y, a cuya sombra, venía a acogerse finalmente el Ensayo de Marina sobre el romance castellano al que nos hemos referido al principio. Ya en I7ıo Leibniz, en su Ensayo sobre el origen delos pueblos deducido principalmente de las indicaciones proporcionadas por las lengua, había llamado la atención sobre la condición de las lenguas como auténticos documentos de la antigüedad, con los que era posible adentrarse en los orígenes remotos de los pueblos $^{28}$. Corresponde no obstante a Nicolas Fréret, el mérito de haber incorporado la historia de las lenguas como una herramienta imprescindible dentro de su plan de rescribir la historia universal de los orígenes. Concluido en la década de los cuarenta, sus Vues générales sur l'origine \& mélange des anciennes Nations, resumía los resultados de sus investigaciones sobre los pueblos de la India, Italia, los Cimerios, Grecia y los antiguos Galos. Su propuesta fundamental radicaba en el estatus heurístico que se confería a la lengua a efectos de esclarecer los orígenes de una nación: «la connaissance du langage que parloit une nation nous conduit a celle de son origine \& du pays ou elle a dû sortir d'abord $»^{29}$. La propuesta de interacción entre lengua y nación de Fréret anunciaba las líneas generales de una reflexión que, centrada en los orígenes del lenguaje, ocuparía como es sabido, a las mejores cabezas de la segunda mitad de siglo, de Condillac a Momboddo, Turgot, Rousseau o el propio Hervás y Panduro. De esta forma -como ha señalado Mercier-Faivre refiriéndose a ese momento- se fue rompiendo con un pasado que «mezclaba lenguas y naciones en un mismo mito originario, próximo a la tradición bíblica»; la definición misma de la nación «dejó de remitirse al derecho divino o a las genealogías míticas para apoyarse sobre hechos observables y sobre la historia». Fue imponiéndose así una perspectiva sincrónica y comparativa que fortalecía la posición de la nación sobre la que, finalmente, pasaría a definirse la lengua ${ }^{30}$.

La discusión en torno a la de la lengua primitiva no era cuestión que, por lo demás, hubiese estado ausente en el ámbito de la monarquía de España, tal y como en su momento había puesto de manifiesto el debate entre Gregorio López Madera

28. DrOIXHE, 1978: 126-142. SIMONE, 1990: II, 350-355.

29. Sobre el contexto y significado de Fréret, que muere en 1749, ver GRELL, 1994: 51-73 y 1993: 84-92.

30. Mercier-Faivre, 1995: 164 y 169-70. 
y Bernardo de Aldrete ${ }^{31}$. La decadencia experimentada por la monarquía a lo largo del siglo XVII suscitó una reflexión interna que no tardó en incluir al lenguaje como demostración de una corrupción a la que supuestamente la habrían conducido los excesos del siglo del Barroco. Armada de una narrativa propia que buscaba desmarcarse de la tradición cultural de la Casa de Austria, la nueva dinastía hizo bandera de la propuesta de regeneración de la lengua. Tal es el contexto, como es sabido, que dio lugar al nacimiento de la Real Academia Española (I7I3), cuyo cometido no era otro que el de combatir «los errores en que se halla viciado el idioma español con la introducción de muchas voces bárbaras e impropias», unas «novedades» en suma que habían dañado seriamente el «crédito y lustre de la Nacion». Se ganaba así una legitimidad cultural que permitía a la dinastía presentarse como efectiva restauradora de la nación a través de la lengua, de acuerdo por lo demás con las orientaciones que le llegaban del país de origen del monarca. Pero ello estaba lejos de anunciar la instauración de una soberanía lingüística que permitiera establecer un completo control sobre una lengua pretendidamente única y bien establecida ${ }^{32}$. Entre otras cosas porque, como ya apuntara en su momento Lázaro Carreter, la propia Academia «carecía de una opinión correcta sobre los orígenes del idioma»33. La intercambiabilidad con la que -dentro del Diccionario- se manejaban los términos castellano/español no venía sino a probar esa indeterminación de partida, contradiciendo una pretensión de exclusividad de voces a favor del primero. En los preliminares del Diccionario ya se apuntaba que, debido a su proceso de formación, la lengua castellana no era sino un «agregado o cúmulo de voces» resultante del conflictivo mestizaje lingüístico del medievo peninsular ${ }^{34}$; la centralidad que de hecho se reconocía al castellano no excluía la presencia de voces procedentes de otros dialectos provinciales. En cualquier caso -y en términos generales- castellano no significaba sino «español de España». Por encima de la diversidad provincial, una memoria de nación conformaba la construcción de la lengua ${ }^{35}$.

Formando parte de un plan de reforma de las «letras españolas», el fundamental Orígenes de la lengua española (I737) de Gregorio Mayans era una primera respuesta a los problemas de esa encrucijada. Haciendo suya una propuesta de Aldrete, el erudito y crítico valenciano rechazaba la posibilidad de una sola lengua primitiva de España, considerando al castellano como resultado de las ya referidas dominaciones que habían afectado a la península. A la hora de explicar los idiomas Mayans abandonaba cualquier esencialismo lingüístico para actuar tan sólo «con elementos abarcables que permitan vislumbrar la fuente ignorada». Su convicción de que las lenguas «suelen ser tantas como dominaciones» imponía la necesidad de mantener

31. Un debate por lo demás cuyos supuestos nada tenían que ver con los de Fréret. Sobre la complejidad y alcance de ambas posturas, WOOLARD, 2004. LLEDÓ-GUILLEM, 2010. BINOTTI, 2012: 149-172.

32. Sobre esas conexiones ver Fernández AlbalAdejO, 2007: 125-147. GARCíA-FolgAdo, 2004, y el planteamiento que, contradiciendo opiniones habituales, propone para el caso francés MERLIN, 1994.

33. LÁzAro Carreter, 1972: 25.

34. En sintonía todo ello con las propuestas de Aldrete y en una formulación que, posteriormente, inspiraría las páginas preliminares del Diccionario de Terreros.

35. «Lengua» no era sino «el conjunto de de voces y términos, voluntariamente elegidos, con que cada Nación explica sus conceptos» Diccionario, t. IV, 1734. 
la mirada presentista del historiador; a la hora de analizar una lengua viva, sostenía el valenciano, «debemos entender el pueblo que hoy es, no el que fue ${ }^{36}$. Un propuesta cuyo peligro fue rápidamente denunciado desde el Diario de los Literatos de España con el argumento de que «buscar el origen de una lengua en el cuerpo civil de una nación [era] es la anatomía de mayor juicio... que se puede celebrar en el theatro de la historia» ${ }^{37}$. Obra del académico Martínez Salafranca la respuesta, independientemente de razones personales, ponía en evidencia una creciente desafección entre la Academia y Mayans, que no había dejado de manifestar serias reservas a propósito del Diccionario. Además de prolongarse en el tiempo, el desencuentro se extendería a otros ámbitos ${ }^{38}$. Así, la noticia de que Mayans venía recogiendo materiales para la elaboración de una gramática española llevó a Salafranca a censurar elogiosamente la Gramática de la lengua castellana de Benito Martínez Gómez Gayoso publicada en I743, un fiel reflejo -al decir de Lázaro Carreter- de «la tradición normativa de las gramáticas anteriores» ${ }^{39}$.

En última instancia el enfrentamiento ponía de manifiesto la importancia que empezaba a tomar la gramática ${ }^{40}$. Una situación parecida se experimentaba en Portugal. No sin problemas, Luis Antonio Verney daba a conocer por esas fechas (I746) el Verdadeiro método de estudar para ser útil à República è à Igreja, una denuncia de los métodos tradicionales de enseñanza dominados por los jesuitas donde se postulaba que «qualquiera Gramática de una lengua que no es nacional» se debía de «explicar en la lengua que uno sabe»41. La edición española del libro de Verney (1760) intentaba consolidar esa orientación. A ella se acogía en concreto el Arte del Romance castellano (1769) de fr. Benito de San Pedro, donde se reiteraba que «el fundamento para la renovación de todas las artes, letras y ciencias es el cultivo de la lengua propia». Partiendo del hecho de que las gramáticas en circulación resultaban «defectuosas en reglas, en observaciones, y especialmente en principios generales», el religioso se encaminaba a sujetarla [la lengua] a reglas» ${ }^{42}$. Sin dejar de reconocer la deuda que esa empresa tenía con Mayans (de quien incluía una carta en sus primeras páginas), su Arte se acogía abiertamente a los supuestos de los gramáticos racionalistas, intentando poner de manifiesto -como apunta $\mathrm{M}$. Lliteras- las oportunas correspondencias «entre categorías lógicas y categorías gramaticales» ${ }^{43}$, persiguiendo en última instancia que «todo buen Español sepa su lengua por principios y por razón». Imprescindible como era, ese saber del lenguaje «por razón y ciencia» debía conjugarse con lo que paralelamente suponía la aportación "por plática y uso», que venía a constituir como «la simetría del razonamiento». Se hacía necesario por ello acostumbrarse «a leer diligentemente las obras de los buenos Autores»; de hecho, la posibilidad de llegar a ser «un

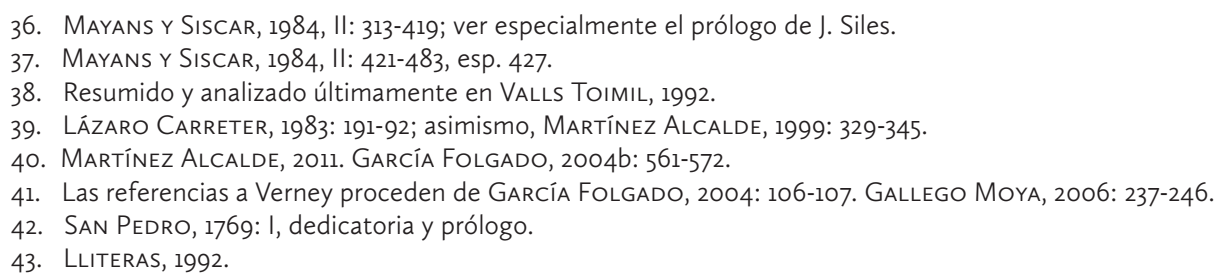


buen Romancista» dependía de la tácita circularidad que operaba entre uno y otro supuesto: «Ni la lección de los buenos libros Españoles sin el Arte, ni el Arte sin la lección de los libros españoles». Tanto como lección, los libros en cuestión implicaban también una elección, elección de un tiempo que se intentaba blindar y estabilizar a toda costa. Pocas dudas se albergaban en este sentido a la hora de reconocer al «siglo decimosexto» como el momento de «la grandeza y perfección de nuestra lengua», como el momento en el que podía constatarse un elenco de autores con la capacidad suficiente para constituirse en canon de nación, de una nación conformada así por la lengua. Admitiendo la influencia determinante que había tenido «la extensión del imperio» en ese desenlace, Fray Benito enfatizaba su «método» gramatical por razones de estricta «utilidad de la Nación». En última instancia las lenguas siempre habían seguido «la condición de los pueblos»y, el esplendor de aquellas, no venía sino a reflejar «el genio original de la Nación». La proyección patriótica de ese supuesto retroalimentaba finalmente el propio interés político: sabido era «lo mucho que importa al Estado formar sus ciudadanos en el patriotismo», siendo el cultivo de la lengua propia uno de «los medios más poderosos al respecto».

El énfasis lingüístico-nacionista del escolapio tampoco era ajeno por otra parte a orientaciones -ya más coercitivas- que la monarquía venían haciendo públicas desde mediados de los sesenta. Y en las que además de instar a la enseñanza de las primeras letras, latinidad y retórica en lengua castellana, requerían asimismo a los responsables de su aplicación la «exacta observancia y diligencia en extender el idioma general de la Nación» ${ }^{44}$. La prioridad otorgada a la lengua castellana debe entenderse por lo demás en sus justos términos. Una tras otra, todas las disposiciones dejaban constancia que se trataba de ampliar la parcela que venía correspondiendo al castellano en la enseñanza, si bien dentro de un sistema que culturalmente se asentaba sobre la preeminencia latín y el dominio de los jesuitas hasta el momento de su expulsión. El propio plan de reforma universitaria de Mayans ( 1767 ) conjugaba el apoyo a la lengua vulgar con la defensa del latín clásico45. Veinte años después el gramático Juan Pablo Ballot hacía notar que «el conocimiento de la lengua propia de la nacion», más allá de hablarla con corrección y pureza», no constituía sino el paso previo para aprender el latín ${ }^{46}$, que tardaría todavía un tiempo en perder su condición de lengua de ciencia y lengua internacional. La instauración oficial del castellano en la enseñanza -no exento de alguna vuelta atrás- no se produjo hasta $18 \mathrm{I}^{47}$.

La aparición en I77I de la Gramática de la lengua castellana compuesta por la Real Academia Española Española vino a oficializar en cualquier caso las nuevas orientaciones. Cuatro años antes el Duque de Alba, decano del Consejo de Estado y director de la Corporación, había hecho notar a los académicos la necesidad de disponer de «una gramática completa en nuestra lengua para aprender con método

\footnotetext{
44. Así se dispone en la Real Cédula de 23 de junio de 1768. Ver la referencia en García Folgado, $2004: 97$.

45. Martínez Alcalde, 1999: 343-345.

46. García Folgado, 2004: 108-109.

47. Gutiérrez Cuadrado, 1987: 237-252. García Folgado, 2004: 103-114.
} 
y sobre principios y reglas seguras ${ }^{4}{ }^{4}$. Quitando protagonismo al Diccionario y treinta años después de la Orthographia Española, la Gramática daba a luz una codificación del castellano que conocería cuatro ediciones hasta 1796 . Se planteaba así un «Arte del bien hablar» cuyas reglas se obtenían de «la observación del habla», de un habla que se otorgaba a sí misma condición autoreferencial, canónica. Y que presuponía una interacción permanente entre lengua y el uso actual de la misma. Como se sabe el conflicto entre teoría lingüística y práctica de la lengua venía ocupando a la llustración lingüística desde sus comienzos, en una dinámica que finalmente condujo a la formulación de acuerdos. Con la confección de las gramáticas racionalistas los ilustrados no buscaban tanto establecer un «código gramatical» cuanto «definir el uso de la lengua» de acuerdo con la práctica de los mejores autores ${ }^{49}$. En esa línea, el reconocimiento del uso «como «dueño y árbitro» era supuesto de partida de la Corporación española, que reconocía acogerse al criterio de «los célebres gramáticos modernos». Siendo objetivo declarado el de preservar los desmanes del habla, la presencia de una «presión normativa ejercida sobre el uso «resultaba inevitable, si bien esa vigilancia se desenvolvía dentro de un normativismo moderado ${ }^{50}$.

La necesidad de establecer un canon de autores perceptible ya en los trabajos de Mayans y Miraflores, se hacía ahora más notoria. La Academia había venido realizando una limpieza léxica del idioma como reacción a los excesos del barroco pero, avanzada esa tarea -y a diferencia de lo ocurrido en Francia ${ }^{5 \mathrm{I}}$ - no resultaba fácil recuperar unas figuras de autoridad cuya memoria y entidad aparecía difuminada. En parte, la irrupción del neoclasicismo intentaba cubrir ese hueco si bien al precio de instaurar el casticismo, una «fuerza activa» cuyo fin no era otro que el de «resucitar el pasado lingüístico nacional, basando en él toda la literatura posterior» ${ }^{2}$. La búsqueda y utilización de arcaísmos por parte del casticismo se convirtió en la cuestión central de un debate que domina la historia del último tercio del siglo XVIIl y la primera mitad del siglo XIX. Y del que en última instancia derivaría el purismo como «faceta negativa» de esa actitud ${ }^{53}$.

$\mathrm{Su}$ presencia se hacía notar ya en el ámbito de la Academia y el propio Ensayo Histórico-Crítico de Martínez Marina era prueba de ello. Buena parte de los argumentos del texto se dirigían a rebatir la Declamación contra los abusos introducidos en el castellano, una memoria presentada por José de Vargas Ponce al concurso convocado por la Academia de la Lengua en I79I y editado en I793 sin nombre de autor, consignándose en la portada del libro su condición de declamación «presentada y no premiada». Marina se refería a él como el «autor anónimo» de la Disertación, pero parece difícil de admitir que el Director de la Academia no reconociese a quien, en el mismo año en que se convocaba el concurso (I79I), había accedido a una plaza de numerario en su propia Academia. Manifiesto del arcaísmo

48. Sarmiento, 1984: 19-23. San Vicente Santiago: 1996: 606-611.

49. GUSDORF, 1973: 319-328.

50. SARMIENTO, 1984: $39-45$

51. Ver a este respecto, GUSDORF, 1973: 318-328.

52. LÁzARo CARRETER, 1983: 255-290, esp. 234-237.

53. LÁZARO CARRETER, 1983: 259-261; prolongando el análisis del fenómeno al siglo XIX, ver también DURÁN LÓPEZ, 2010: 117-180, esp. 118. 
casticista, la Declamación de Vargas Ponce había sido objeto de una acerba crítica por parte de Juan Pablo Forner quien, en un folleto de I795, había acusado a Vargas de plagiario y censurado asimismo la utilización de un lenguaje y estilo anticuados ${ }^{54}$.

El Ensayo de Marina no se inmiscuía por lo demás en la batalla general que los neoclásicos libraban contra los puristas Sus objeciones eran de otro orden, más histórico-metodológicas que propiamente literarias. Le inquietaba que el asentamiento del casticismo reabriese el laberinto babélico, una cuestión que desde el principio quería dejar muy en claro, es decir, no la tomaba en consideración. Significativamente su trabajo se ofrecía como una reflexión sobre «la noble y excelente facultad de hablar», una «dote y prerrogativa del hombre» con la que el «Criador» le situó por encima de los animales. Una «máquina» tan «sencilla en sus principios» como «complicada en sus efectos», con un elenco de cuestiones (¿en qué consiste que el hombre hable, cómo se han formado las lenguas, cómo se han alterado y dividido, porqué se perfeccionan y corrompen?) cuya resolución resultaba prioritaria a la hora de emitir algún juicio sobre «la formación, alteración y perfección» de nuestra lengua, de la castellana. En este aspecto Condillac y Rousseau constituían las referencias básicas de Marina. Reconocía para empezar las diferencias que le separaban del «sistema» de Condillac que, si bien «adoptado por los más célebres psicologistas», le parecía «ciertamente incomprensible». No cabía imaginar una época en que «los hombres derramados por los bosques careciesen del uso de las lenguas», sobre todo cuando los propios «documentos de la historia» los representaban «reunidos en sociedades».

Marina no ocultaba sus preferencias por Rousseau, decantándose por el «común consentimiento» frente a la «formación mecánica de las lenguas». Lejos de resultar «un don de la naturaleza» la facultad de hablar no era sino un talento o arte adquirido como todos los demás». La clave de todo el proceso debía de situarse en la educación. Hablamos porque otras personas nos enseñaron a hablar, remontándonos a lo largo de una cadena que indefectiblemente nos llevaría a un primer hombre educado ya no «en la escuela de otro hombre sino en la de Dios». No cabía imaginar, afirmaba Marina, «una teoría de las lenguas más excelente». Perdían así todo su sentido los trabajos de quienes, desestimando ese punto de partida, había venido indagando sobre «el raro fenómeno del origen de las lenguas». En la imposibilidad de reconocer la «naturaleza y circunstancias» de esa lengua primitiva era obligado contemplar las cosas de otra forma. Bastaba con tener presente que el hombre, «en virtud de su constitución, de su libertad, organización y perfectibilidad» había quedado habilitado para recibir, rectificar u olvidar «distintas ideas» ${ }^{55}$. Y ese fue el principio que movió la alteración de la lengua primitiva y la posterior formación de los dialectos. Como en el planteamiento de Valdeflores, «el espíritu más filosófico» de Marina se imponía a quienes se empeñaban en continuar por los derroteros de «una erudición caprichosa y forzada» ${ }^{56}$.

54. DURÁN LÓPEZ: 2010 y 2012, LXX

55. Martínez Marina, 1805: 10

56. Sobe ese debate central filosofía-erudición, ver GRELL, 1992: 19-52. 
Más allá de ese ámbito íntimo, la inescindible condición social del individuo, su relacionabilidad, había marcado obligadamente la dinámica de cambios en las lenguas. Los progresos en las artes y ciencias, las revoluciones políticas en el seno de los estados, así como sus crecientes «enlaces» en industria y comercio» ponían de manifiesto que «las lenguas no se pudieron enriquecer sino por medio de un comercio inteligible de ideas y pensamientos». Las lenguas más ricas del universo no eran sino «rastros y reliquias de otras más antiguas ignoradas y desconocidas... ríos engrandecidos por la avenida de arroyos y torrentes». Esa había sido la causa del engrandecimiento de la «lengua romana» y no otro había sido el camino de la «nuestra castellana». En consecuencia, esos mismos supuestos eran los que debían tenerse en cuenta a la hora de indagar la lengua que pudieron hablar «los antiguos españoles en los tiempos fabulosos de nuestra historia». Las «investigaciones» de «nuestros literatos» sobre el período anterior a la llegada de cartagineses y romanos no tenían más entidad que la de una «fabula». La simple aplicación de «los principios de una buena filosofía» permitía suponer, todo lo más, que se trataría de una lengua «mezquina, pobre y muy limitada». De ahí que viviendo en un estado semejante «al de las Antillas y otros países nuevamente descubiertos» acogiesen sin mayor resistencia las ciencias, artes, costumbres, ideas de «virtud, derecho y sociabilidad» de los «conquistadores romanos». Hasta el extremo de que «la lengua del Lacio se hizo universal, única e invariable en la península» y de que, los españoles, «se hicieron romanos» ${ }^{57}$.

Marina se oponía así abiertamente al «autor anónimo» de la Declamación, a su defensa de un antiguo «lenguaje nacional» anterior al momento romano y constatable en «el uso de algunas voces originarias del país». Una posibilidad que en ningún caso se veía avalada por huella alguna en monumentos, inscripciones y demás. Todo indicaba por el contrario que «el lenguaje común de la nación, de los sabios y del pueblo, era la lengua latina». Para nuestro académico -en línea con Nebrija- la suerte de los idiomas aparecía vinculada a la de las ciencias y las artes, quedando a su vez estas últimas al albur de los imperios. De ahí que «la irrupción de los bárbaros del norte» acabase con la pureza y hermosura del latín, aunque ese desenlace debía matizarse en relación con la península. Frente a la idea de una corrupción general del latín defendida por Aldrete, Marina postulaba su continuidad en el ámbito peninsular, consecuencia de la previa contaminación cultural romana del pueblo invasor. Abundantísimos «monumentos» y el lenguaje mismo del «cuerpo legislativo» visigodo así lo atestiguaban. Los «barbarismos» y «alteraciones» que pudieron introducirse entonces carecían de entidad para corromper «nuestro antiguo lenguaje». No sucedió así con la invasión árabe, la «revolución... más extraordinaria, rápida y violenta que hasta entonces habían visto los siglos». El abatimiento del lenguaje latino fue tan rápido como contundente. Tanto fue así que a mediados del siglo IX podía darse por consumado ${ }^{58}$.

57. Martínez Marina, 1805: 11-13.

58. Martínez Marina, 1805: 5-18. 
Obviamente el relato completo de ese proceso implicaba no perder de vista al «corto número de españoles independientes» que optaron por defenderse «entre las asperezas de los montes asturianos». A ellos cabía imputar que, al tiempo que ponían los cimientos de «una nueva monarquía», mudasen progresivamente su «antigua lengua». El roman, el castellano, fue gestándose en ese preciso contexto, donde «la ignorancia, negligencia y descuido» en el cultivo de su lengua latina fue de la mano con una evolución política contraria al reconocimiento de «un solo cetro y un solo códice legislativo». Ese particularismo fue la causa de la interminable serie «guerras intestinas y domésticas» que presidieron ese proceso que, a principios del siglo XIII, hacían irreconocible la lengua del Lacio. En el camino se había ido forjando un lenguaje «sin artificio y con total independencia de las reglas gramaticales», con un «orden sencillo» próximo a la «naturalidad de las lenguas orientales» y cada vez más alejado de su lengua madre. A mediados del siglo XI la llegada de Alfonso VI supuso un impulso decisivo: el monarca consiguió reunir a la vez «los pequeños estados»y los «ánimos» que, de esta forma, comenzaron a reconocer «una sola dominación». Pudo asentarse con ello «un mutuo y nuevo comercio de ideas, pensamientos y de vocablos entre asturianos, gallegos, vizcaínos, leoneses y castellanos con parte de Navarra», actores que «reputándose por un solo cuerpo», pasaron a «promover la felicidad común de la nación». La conquista de Toledo, «centro de España», resultó el momento culminante.

El eco exterior de «tan grave y sagrada empresa» propició la llegada de gascones, francos y alemanes», atraídos por ventajosas condiciones de acogida ${ }^{59}$, pero las huellas visibles de esa influencia resultaban de mucha menos entidad que las impresas por la lengua arábiga de los mahometanos, la nación «más erudita y culta del mundo en el siglo XIl y XIIl» y cuyos enlaces de «orden moral y político» con los españoles ponían de manifiesto un mayor alcance y penetración. De hecho esa herencia era responsable de la «falta de declinaciones» y, por lo mismo, de «la multitud de artículos y preposiciones» que, al decir de Vargas Ponce, no venían sino a «enchir el discurso». Una argumentación que Marina consideraba poco sostenible a la vista de ejemplos cercanos (el italiano) o el de los propios idiomas orientales. El uso de artículos constituía en realidad «una perfección y gracia de nuestra lengua».

Aunque en grado desigual, latín y árabe estaban en la base de su esplendor. Para Marina el romance castellano, tal como aparecía a comienzos del siglo XIII, se había levantado sobre «las ruinas del idioma latino» aunque «enriquecido con empréstitos y dones quantiosos del abundante árabe». Las «riquezas» del idioma español, insistía Marina, su «genio, constitución, gramática, sintaxis, elementos y voces» eran debidas a esos dos idiomas, con su debida proporción: tres cuartas partes al latín y el resto al árabe. Otros acreedores no los había. Los reclamos de Vargas Ponce y otros casticistas en favor de la presencia de voces púnicas, celticas y góticas no cabían; salvando algunas excepciones casi todas ellas remitían en realidad al latín o al árabe. A lo largo del siglo XIII Fernando Ill y Alfonso X culminarían el proceso. Este último «eternizó su nombre así como el idioma castellano

59. Martínez Marina, 1805: 22 y 34 . 
con el código del fuero de las leyes ${ }^{60}$. Contrastando con ese tiempo central, los dos siglos posteriores aparecían como un paisaje desolado. «Puerilidad» y «grosería» habrían sido en realidad los rasgos dominantes «en el común de los escritores de los siglos XIV y XV», incluyendo entre ellos a Juan de Mena y al marqués de Villena. La falta de tratados de gramática y ortografía fue determinante en ese desenlace, independientemente de una inestabilidad social y política que impedía «cultivar las lenguas sabias». Conduciendo las cosas al punto donde quería llevarlas, Marina procedía a magnificar la importancia que habían tenido «las revoluciones políticas acaecidas a fines del siglo quince y continuadas con no menor prosperidad en el diez y seis». Semejante cambio político fue acompañado de transformaciones (técnicas, comerciales, geográficas) de no menor entidad, como consecuencia de las cuales «la magestad de la nación española llegó a la cumbre de la prosperidad». Ese fue también el momento en el que tanto el nombre de Castilla, como su lengua, «ocupó toda la tierra» ${ }^{61}$.

Si bien enriquecido «con voces y signos de ideas hasta entonces desconocidas», la lengua requirió en cualquier caso el esfuerzo unos cuantos «doctos españoles» hasta llegar «a la cumbre de la perfección». Todavía la fascinación que se sentía por Grecia y Roma hizo que se mirara «con cierta especie de desprecio a los romancistas», a gentes que como Ambrosio de Morales o Fr. Luis de León nunca tuvieron al idioma español por inferior al «ático» o al «romano». El esfuerzo de esos insignes escritores fue el que consiguió llevarle finalmente a la «perfección», un término cuyo sentido e importancia estratégica Marina consideraba necesario aclarar. No se trataba de la «mudanza de algunas partículas y conjunciones», de la «mutilación de los vocablos», del «trueque recíproco de las letras» o de la presencia de «voces prolongadas compuestas de muchas sílabas». La perfección de un idioma, puntualizaba nuestro clérigo, «consiste en la riqueza, copia y variedad de signos a propósito de representar todas las ideas del espíritu», tanto «las simples como las compuestas, tanto las que dicen relación a los seres físicos como las que se refieren a objetos abstractos y morales»; un idioma capaz en última instancia de «expresar naturalmente la inmensa fecundidad de las producciones del alma», de que las «[palabras] trasladadas, tropos y metáforas se ajusten debidamente a la naturaleza». Establecida esa dinámica lingüística, la explotación de la capacidad inventiva habría de ir seguida por una recta colocación de las partes de la oración, en un proceso que debía de «imitar y seguir no tanto el método de las lenguas sabias, quanto el orden y subordinación que tienen las ideas en el entendimiento». Esos habían sido los motores que en su momento habían estado detrás de las «perfecciones de nuestro idioma». Y tal era el camino a seguir ${ }^{62}$.

Martínez Marina formalizaba así una ruptura cuyo alcance no debe escapársenos. $\mathrm{Su}$ anclaje cultural en el metalenguaje ilustrado de naturaleza cerraba la puerta a las ensoñaciones babélicas sobre la lengua propia. Esta última, de otra parte, acreditaba

\footnotetext{
6o. Martínez Marina, 1805: 37-40 y 44-52.

61. Martínez Marina, 1805: 54-55.

62. Martínez Marina, 1805: 57-58.
} 
más que sobradamente su capacidad para ofrecerse, sin complejos, como autoreferencia excluyente en cualquier proceso de regeneración, de convertirse en su propio fénix. La posibilidad de llevar adelante esa empresa no era algo que dependiese en exclusiva de la fuerza interior de la lengua. El recordatorio de Nebrija de nuevo cobraba fuerza: existiendo como existía una unión «inviolable y esencial... entre la prosperidad de los estados y la de las artes, ciencias y lenguas», el éxito de la empresa imponía obligadamente un proceso coral, no exento de una precisa jerarquía. Las lenguas en efecto habían venido siendo compañeras de imperio, y ese era el papel que correspondía a la «lengua nacional» en el momento en el que la monarquía intentaba reconstruir las bases de su antiguo poder. En esa dimensión lingüística la operación, en realidad, podía darse por concluida. Un siglo después de la llegada del «augusto Felipe de Borbón», «el cuerpo de sabios escogidos» que era la Real Academia Española había cumplido fielmente con la tarea encomendada: «Con su gramática y ortografía fixó para siempre la escritura, la pronunciación, el orden y la sintaxis»; su «gran diccionario erigió al idioma español un monumento eterno». Movida por un «genio» nacional, una codificación de la lengua, una constitución, felizmente se había instalado. La ubicación tradicional de Martínez Marina como mythmaker político de la nación no debe hacernos pasar por alto la importancia de una tarea previa que, a través del Ensayo sobre el romance, hizo posible que el sujeto nación pasase de la constitución de la lengua a la de su propio orden político. 


\section{BIBLIOGRAFÍA}

Aguilar Piñal, Francisco, El académico Cándido María Trigueros (I736-I798), Madrid, Real Academia de la Historia, 200I.

Almagro-Gorbea, Martín, «Pedro Rodríguez Campomanes y las «antigüedades»», Campomanes en su segundo centenario, Madrid, Real Academia de la Historia, 2003: II7-I59.

Álvarez Martí-Aguilar, Manuel, La Antigüedad en la historiografía española del siglo XVIII: el Marqués de Valdeflores, Málaga, Universidad de Málaga, I996.

BinotTı, Lucia, «Historicizing Language, Imagining People: Aldrete and Linguistic Politics», Cultural Capital, Language and National Identity in Imperial Spain, Tamesis, Woodridge, 20I2: I49-I72.

Borghero, Carlo, La certezza e la storia. Cartesianismo, pirronismo e conoscenza storica, Milán, Franco Angeli, I983.

Brochart, Samuel, Geographía Sacra, Cadomi, Petris Cardonelli, i646.

De la Huerta, Francisco Manuel, «Disertación sobre si la Mitología es parte de la Historia, y como deba entrar en ella», en Fastos de la Academia de la Historia, Madrid, Real Academia de la Historia,I740: 63-I95.

Cruz Andreotti, Gonzalo y WulfF Alonso, Fernando, «Tartessos en la historiografía del XVIII al XIX: creación, muerte y resurrección de un pasado utópico», José Luis Beltrán y Fernando Gascó (eds.), La Antigüedad como argumento, Sevilla, Universidad, I993: I7I-I89.

Cruz Andreottr, Gonzalo y WulfF Alonso, Fernando, «Ancient History and Enlightenment: Two Spanish Histories of the Eighteenth Century», Storia della Storiografia, I (I993b): 75-94.

Droixhe, Daniel, La linguistique et l'appel de l'histoire (I600-I80o), Droz, Ginebra, Droz, I978.

Droixhe, Daniel, «La crise de l'hebreu langue-mère au XVII siècle», en Chantal Grell y François Laplanche (eds.), La République des Lettres et l'histoire du judaisme antique. XVI-XVIII siècles, Paris, Sorbonne, I992: 65-99.

DURÁN López, Fernando, «Arcaísmo, casticismo y lengua literaria: alrededores de algunas cuitas de José de Vargas Ponce y sus contemporáneos», en Victoriano Gaviño y Fernando Duran (eds.), Gramática, canon e historia literaria (I750 y I850), Madrid, Visor libros, 20IO: II7-I80.

Durán López, Fernando, Introducción a Obras escogidas de José de Vargas Ponce, Sevilla, Fundación Manuel Lara, 2012.

Dziembowsky, Edmond, Un nouveau patriotisme français, I750-I770. La France face a la puissance anglaise a l'époque de la gerre des Sept Ans, Oxford, Voltaire Foundation, I998.

EIROA Rodríguez, Jorge Juan, «Las antigüedades hebreas en el siglo XVIII», Martín AlmagroGorbea y Jorge Maier Allende (eds.), De Pompeya al Nuevo Mundo, La Corona española y la arqueología en el siglo XVIII, Madrid, RAE, 2012: 245-253.

Eriksson, Gunnar, The Atlantic Vision. Olaus Rudbeck and Baroque Science, Canton, Watson Pub Int., I994.

Fernández Albaladejo, Pablo, Materia de España. Cultura política e identidad en la España Moderna Madrid, Marcial Pons, 2007.

Fernández Albaladejo, Pablo, ««Spanish Atlanteans»: Crisis of Empire and reconstruction of Spanish Monarchy (I740-I672)», Culture\&History Digital Journal, 4 (2), December 2015.

Gallego Moya, Elena, «La enseñanza del latín en el Verdadero Método de Estudiar de Verney», Esteban Antonio Calderón, Alicia Morales, Mariano Valverde (eds.), Koinós 
Lógos. Homenaje al profesor José García López, Murcia, Servicio de Publicaciones de la Universidad de Murcia, 2006: 237-246

García-Arenal, Mercedes y Rodríguez, Fernando, Un Oriente español. Los moriscos y el Sacromonte en tiempos de la Contrareforma, Madrid, Marcial Pons, 2010.

GARCíA-Folgado, María José, «Motivaciones para el estudio de la gramática española en el siglo XVIIl», Analecta Malacitana, I (2004): 9I-II6

García Folgado, María José, «La gramática a finales del siglo XVIII (I769-I8oo). Objetivos y fuentes», en Nuevas aportaciones a la historiografía lingüística. Actas del IV Congreso Internacional de la SEHL, Madrid, Arco Libros, 2004b: I, 56I-572.

Grell, Chantal, L'Histoire entre érudition et phiosophie, París, PUF, I993.

Grell, Chantal, «Nicolas Fréret, la critique et l'histoire ancienne», Chantal Grell, y Catherine Volpilhac-Auger (eds.), Nicolas Fréret, légende et verité . Colloque 199I, Oxford, Voltaire Foundation, 1994: 5I-73.

Grell, Chantal, Le Dix-huitième siècle et l'antiquité en France 1680-I789, Oxford, Voltaire Foundation, I995.

Gil, Juan, Mitos y utopías del Descubrimiento, Madrid, Alianza, I980

Glıozzı, Giuliano, Adamo e il Nuovo Mondo, Florencia, La Nuova Italoa, I977.

GusDorf, Georges, L'Avènement des Sciences Humaines au Siècle des Lumières, Payot, Paris, I973.

GUTIÉRREZ CUADRADO, J., «La sustitución del latín por el romance en la universidad española del siglo XIX», en Universidades españolas y americanas. Época colonial (Valencia, I987), pp.237-252,

Hute, Pierre-Daniel, Commentarius de navigationibus Salomonis, Amsterdam, I693.

HuEt, Pierre-Daniel, Traité sur la situation du paradis Terrestre, París, I70I.

Hute, Pierre-Daniel, Histoire du commerce et de la navigation des Anciens, París, I716.

IbÁÑ̃z De Segovia, Gaspar, Cadiz Phenicia, con el examen de varias noticias antiguas de España, que conservan los escritores Hebreos, Phenicos, Griegos, Romanos y Arabes, Cádiz, Imprenta Don José del Collado, I805,

Laplanche, François, La Bible en France entre mythe et critique, XVI-XIX siècle, París, Albin Michel, 1994.

Laurens, Henry, «Orient et Origine», en Chantal Grell y Christian Michel (eds.), Primitivisme et mythes des origines dans la France des Lumières, I680-I720, París, Sorbonne, I989: 205-218.

Lázaro Carreter, Fernando, Crónica del Diccionario de Autoridades (I7I3-I740), Madrid, Real Academia Española, I972.

LÁZARo CARRETER, Fernando, Las ideologías lingüísticas en España durante el siglo XVIII, Barcelona, Crítica, 1983.

LiDA DE MALKIEL, M. Rosa, «Tubal en España», Ábaco. Estudios sobre literatura española, Madrid, Castalia I970, $\mathrm{n}^{\mathrm{O}} 3$ : II-47

LLEDÓ-GuILlEM, Vicente, «¿Compañera o rebelde. La lengua y el imperio según Bernardo de Aldrete», Bulletin of Hispanic Studies, 87 (20I0): I-I6.

Lliteras, Margarita, «Benito de San Pedro frente a la tradición nebrisense», Bulletin Hispanique, 94, 1992: 506-527

MarTínez AlCALDE, María José, «Mayans y la gramática española del siglo XVIII», en Antonio Mestre (Coord.), Actas del Congreso Internacional sobre Gregorio Mayans, Ayuntamiento de Oliva, I999: 329-345

Martínez AlCALDE, María José, «El retorno de la gramática: los textos de 1743 (Benito Martínez Gómez Gayoso) y I769 (Benito de San Pedro)» en, José Jesús Gómez Asencio 
(dir.), El castellano y su codificación gramatical, Salamanca, Instituto Castellano y Leonés de la lengua, 20II: III, I59-I93.

Martinez Marina, Francisco Antigüedades hispano-hebreas convencidas de supuestas y fabulosas. Discurso histórico-crítico sobre la primera venida de los judíos a España, en Memorias de la Real Academia de la Historia, Madrid, Imprenta de Sancha, I799: Ill, $317-468$.

MARTINEZ MARINA, Francisco, Ensayo histórico-crítico sobre el origen y progreso de las lenguas, señaladamente del romance castellano, en Memorias de la Real Academia de la Historia, Madrid, Imprenta de Sancha, I805: IV, I-63.

MASDeu, Juan Francisco, Historia crítica de España y de la cultura española (Madrid, Imp. Antonio Sancha, I783-1805), 20 vols.

MAYANS y Siscar, Gregorio, Obras completas, Oliva, Ayuntamiento de Oliva, I984, II.

Mederos Martin, Alfredo, «Los estudios fenicios en la España ilustrada», Martín AlmagroGorbea y Jorge Maier Allende (eds.), De Pompeya al Nuevo Mundo, La Corona española y la arqueología en el siglo XVIII, Madrid, RAE, 20I2: 15-33.

Mercier-Faivre, Anne Marie, «La nation par la langue: philologie, nationalisme et nation dans l'Europe de dix-huitième siècle», Michael O'Dea y Kevin Whelan (eds.), Nations and nationalisms: France, Britain, Ireland and the eighteenth-century context (Oxford, Voltaire Foundation, I995: I6I-180.

MERLIN-KAJMAN, Hélène, «Langue et souveraineté en France au XVII siècle. La production autonome d'un corps de langage», Annales, 49 (I994): 369-394.

Momigliano, Arnaldo, «Ancient History and the Antiquarian», Journal of the Warburg and Courtland Institute, I3/4 (I950): 293-304

MorA, Gloria, «Los estudios hebraicos en la España ilustrada. Francisco Pérez Bayer y el origen de las lenguas y escrituras en España», Estudios en Homenaje a L. García Iglesias, Madrid, UAM, 20I0: 425-454.

OlDs, Katrina B., Forging the past. Invented Histories in Counter-Reformation Spain, New Haven, Yale University Press, 2015.

Pouloin, Claudine, Le Temps des origines, París, Champion, 1998.

Rodríguez Campomanes, Pedro, Antigüedad marítima de la República de Cartago, con el periplo de su General Hannon, traducido del griego e ilustrado, Madrid, Imprenta Antonio Pérez de Soto, 1756.

RIDRUEJo, Emilio, «Los tratados de Historia del español bajo el reinado de Carlos IV: las obras de Vargas Ponce y Martínez Marina», en José Jesús Bustos y José Luis Girón (eds.), Actas del VI Congreso Internacional de la Lengua española (Madrid, Arco Libros, 2006: 11, 825-837.

RODRíguez MOHEDANo, Rafael y Pedro, Historia literaria de España desde su primera población hasta nuestros días, Madrid, Imprenta de Francisco Xavier García, I766-I79I.

Rossı, Paolo, I segni del tempo, Milan, Feltrinelli, I979.

Ruiz Veintemilla, Jesús Miguel, «La polémica entre Don Gregorio Mayans y el Diario de los Literatos de España», Revista de Literatura, I (1979): 69-130.

SAN Pedro, Benito, Arte del romance castellano dispuesta según sus principios generales i el uso de los mejores autores, Valencia, Imprenta Benito Monfort, I769.

San vicente Santiago, Félix, «Filología», Francisco Aguilar Piñal (ed.), Historia Literaria de España en el siglo XVIII, Madrid, Trotta, 1996: 593-669.

SARMiento, Ramón, «Introducción» en Gramatica de la lengua castellana, Madrid, Editora Nacional, I984. 
SchNAPP, Alain, «Modèle naturaliste et modèle philologique dans l'archeólogie européenne du XVI au XIX siecles», Javier Arce y Ricardo Olmos (Coords.), Historiografía de la arqueología y de la historia antigua en España, Madrid, CSIC, I99I: I9-23

SimONE, Raffaele, «Seicento e Settecento», en Giulio C. Lepschy (ed.), Storia della lingüística, Bolonia, Il Mulino, I990: Il, 313-395.

Terreros y Pando, Esteban, Diccionario castellano con las voces de Ciencias y Artes y sus correspondientes en las tres lenguas, Francesa, Latina e Italiana, Madrid, Viuda de Ibarra, I786-I793.

VALLS TolmIL, José Luis, «Una polémica gramatical del siglo XVIII», José Antonio Bartol, Juan Felipe García Santos y Javier De Santiago Cuervós (eds.), Estudios filológicos en Homenaje a Eugenio Bustos Tovar, Salamanca, Universidad de Salamanca, I992: 11, 925-940.

VelazQuez, Luis José, Noticia del viage de España hecho de orden del Rey y de una nueva historia general de la nación desde el tiempo más remoto hasta el año de I5I6, Madrid, Imprenta Gabriel Ramírez, 1765.

VIDAL-NACQUET, Pierre, «L'Atlantide et les nations», Representations de l'origine», Cahiers CRLH-CIRAOI, 4 (1987): 9-28.

VIDAL-NACQuet, Pierre, L'Atlantide. Petit histoire d'un mythe platonicien, París, Les BellesLettres, 2005.

Westler, Brendon, «Between Tradition and Revolution: The Curious Case of Francisco Martínez Marina, the Cadiz Constitution, and Spanish Liberalism», Journal of the History of ideas, 76/3 (2015): 394-4I6.

Woolard, Kathryn A., «Is the Past a Foreign Country?: Time, Language Origins, and the Nation in Early Modern Spain», Journal of Linguistic Anthropology, I4 (2004): 57-80.

YAÑEZ De Avilés, Pablo, España en la Santa Biblia. Exposición histórica de los textos tocantes a Españoles, Madrid, Imprenta de Juan Muñoz, I733. 



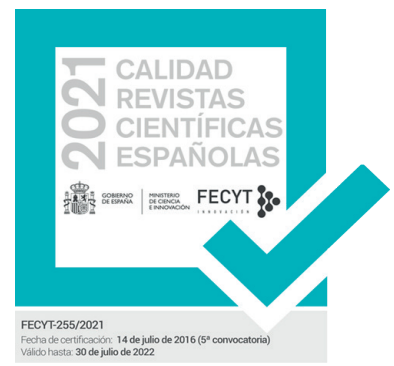

SERIE IV HISTORIA MODERNA

REVISTA DE LA FACULTAD DE GEOGRAFÍA E HISTORIA

AÑO 2021

ISSN: 1131-768X

E-ISSN 2340-1400

\section{4 \\ 西 ESPACIO, TIEMPO Y FORMA}

Monográfico - Special Issue: La política ultramarina de las monarquías ibéricas (circa 1700-1750): una historia de fracasos y éxitos relativos The Overseas Policy of the Iberian Monarchies (Circa 1700-1750): A History of Failures and Relative Successes

15 Roberto Quirós Rosado y MARIA FERnANDA BICALHO La política ultramarina de las monarquías ibéricas (circa 1700-1750): una historia de fracasos y éxitos relativos / The Overseas Policy of the Iberian Monarchies (Circa 1700-1750): A History of Failures and Relative Successes

\section{Guillaume Hanotin}

Defender negocios en tiempo de convulsión política: las elites mercantiles francesas durante la guerra de Sucesión española / Protecting Business in Time of Crisis: French Trademen during the War of Spanish Succession

\subsection{Maria Fernanda Bicalmo}

Ultramarino y el auge de los secretarios de Estado en Portugal durante la primera mitad del siglo XVIII / Sobre este modo de resolver e despachar os negócios. The decline of the Overseas Council and the Rise of the Secretaries of State in Portugal during the First Half of the $18^{\text {th }}$ Century

\section{9}

\section{VALENTINA FAVARò}

El fracaso de los proyectos de reforma en el virreinato peruano de principios

del siglo XVIII. Las propuestas de Carmine Nicola Caracciolo, príncipe de Santobuono the Eighteenth Century. The Proposals of Carmine Nicola Caracciolo, Prince of Santobuono

\section{7}

\section{ROBERTO QUIRÓS ROSADO}

Ecos de un mercantilismo truncado. El conde de Pinos Puente y la diplomacia comercial de Carlos VI en la corte de Lisboa (1723-1724) / Echoes of a Failed Mercantilism. The Count of Pinos Puente and the Commercial Diplomacy of Charles VI at the Court Of Lisbon (1723-1724)

\section{Junia Ferreira Furtado}

Portuguese America under Foreign Threat and the Creation of the Concept of uti possidetis in the First Half of the $18^{\text {th }}$ Century / La américa portuguesa bajo la amenaza exterior y la creación del concepto de uti possidetis en la primera mitad del siglo XVIII

\section{Miscelánea $\cdot$ Miscellany}

\section{José Antonio Mateos Royo}

con Cataluña / Trade Policy and Monetary Circulation in Aragon: Conflicts and Agreements with Catalonia (1535-1565)

\section{Fernando Altoé}

panegíricos atribuidos a la impresion. Un estudio de la trayectoria de dos the Trajectory of Two Panegyrics Attributed to João de Barros

\section{Francisco Velasco Hernández}

reino de Murcia (siglos XVI y XVII) / The Influence of the Berber Corsican on the Late Repopulation on the Coastal Area on the Kingdom of Murcia (XVI and XVII Centuries)

\section{José Antonio Martínez Martínez}

Criados, jornaleros y esclavos al servicio de la familia: la servidumbre de Serfdom of the Muñoz de Otálora in the $17^{\text {th }}$ Century

\section{Víctor Daniel Regalado González-Serna}

Benito de Medina a raíz de su ingreso en el cabildo catedral de Sevilla en 1669 / «Not a Single Good Portuguese». Accusations against Priest Alonso Benito de Medina when Entering the Cathedral Chapter of Seville in 1669

\section{José Herrera Reviriego}

organigrama comercial y militar de la Gober a tólo mitad del siglo XVII / "Only Time will Tell us»: The Role of Taiwan within the Commercial and Military Organization of the Philippine's Governoration during the First Half of the Seventeenth Century

\section{Manuel-Reyes García Hurtado}

de Rande, 1719-1733 / Vicissitudes of the Rescue Companies of the Sunken Ships in the Battle of Rande, 1719-1733

\subsection{Marcos de Miguel Muñoz}

Caballeros in 1769 


\section{4 ESPACIO, TIEMPO Y FORMA}

\section{Javier Tinoco Domínguez}

Tensiones sociopolíticas en el marco del catastro de Ensenada en Jerez de la Frontera: estudio de un conflicto institucional / Socio-Political Tensions within the Framework of Cadastre of Ensenada In Jerez de la Frontera: A Studying of an Institucional Conflict

\section{Pablo Fernández Albaladejo}

Fábulas de origen y gramática de nación en la España del siglo XVIII. A propósito de algunos trabajos de Francisco Martínez Marina / Origin's Fables and Grammar of Nation in the XVIII Century Spain. About some Works by Francisco Martínez Marina

\subsection{José María IÑURRITEgui Rodríguez}

3 Constitución increada: Francisco Martínez Marina y la crítica bíblica / Uncreated Constitution. Francisco Martínez Marina and Biblical Criticism

\subsection{David A. Abián Cubillo}

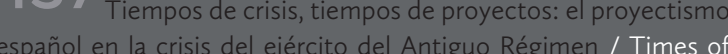
crisis, Times of Projects: The Spanish proyectismo during the Army's Crisis in the Ancient Regime

Taller de historiografía · Historiography Workshop

Ensayos · Essays

\subsection{Christoph ROSEnMüLler}

«Tan peligrosas y feas conspiraciones»: la relación escrita por el embajador austriaco Christoph Migazzi en 1754 sobre la caída del marqués de la Ensenada / «Dangerous and Ugly Conspiracies». The Report of the Austrian Ambassador Christoph Migazzi on the Fall of the Marquis of la Ensenada in 1754

\subsection{Serge Gruzinskı}

Quelle histoire enseigner en 2021 ? / ¿Qué historia enseñar en 2021?

\subsection{Carlos Amate Pizarro}

Las relaciones hispano-chinas en el siglo XVI: síntesis e interpretación a la luz de la reciente historiografía / The Hispanic-chinese Relationship in the XVI Century: Synthesis and Interpretation in the Light of Recent Historiography

\section{Reseñas • Book Review}

521 Bolufer Peruga, Mónica, Arte y artificio de la vida en común. Los modelos de comportamiento y sus tensiones en el Siglo de las Luces, (Julio ArRoyo VozmediANo) 


\section{4 ESPACIO, TIEMPO Y FORMA}

525 Melón, Amando, Alejandro de Humboldt. Vida y obra (Carlos Martínez Shaw)

52 Commentary to Tatiana Seijas' review of The Atlantic World and the Manila Galleons: Circulation, Market, and Consumption of Asian Goods in the Spanish Empire (JosÉ LuIs GASCH TOMAS)

533 Braguier, Laurey, Servantes de dieu. Les beatas de la Couronne de Castille (1450-1600) (Manuela Águeda GARCÍA-GARRIDO)

539 Romeo, María CRuz; SAlomón, María Pilar; TABANERA, Nuria (eds.): Católicos, Reaccionarios y Nacionalistas. Política e identidad nacional en Europa y América Latina Contemporáneas (JAVIER M. Dos SANTOS)

54 Heredia López, Alfonso Jesús, El control de la corrupción en la Monarquía Hispánica. La Casa de la Contratación (1642-1660) (José Manuel Díaz Blanco)

17 Andújar Castillo, Francisco, El Atila de Madrid. La forja de un banquero en la crisis de la monarquía (1685-1715) (Aitor Díaz PAREdes)

551 Serrano Aviles, Javier y Mojarro, Jorge (eds.) Prada GonzALEZ, María (coord. de ilustraciones), En el archipiélago de la Especiería. España y Molucas en los siglos XVI y XVII (İ̃̃ıGo VALPUESTA VILLA)

555 Díaz Ceballos, Jorge, Poder compartido. Repúblicas urbanas, Monarquía y conversación en Castilla del Oro, 1508-1573 (JUAN SEbAstián Gómez GonZÁleZ)

51 Edelmayer, Friedrich, Massimiliano II, Filippo II I'Italia imperiale. II marchesato di Finale, i diritti imperiali e il «camino spagnolo» (RAFAEL VALLADARES)

56 Escribano-PÁEZ, José M., Juan Rena and the Frontiers of Spanish Empire, 1500-1540 (DAvid Martín Marcos)

56 ARNOLD, David, La Era de los Descubrimientos (1400-1600), Madrid, Alianza Editorial, 2021, 184 Pp., ISBN: 978-841362-172-2 (CARlos Amate Pizarro) 